\title{
Pemanfaatan Buah Sisa Sebagai Bioetanol dan Pupuk Organik
}

\author{
Ricky Yadi ${ }^{1^{*}}$, Eddifa Rahman ${ }^{2}$, Vetrio Monandes ${ }^{3}$ \\ ${ }^{1,2,3}$ Balai Pengembangan Produk dan Standardisasi Industri Pekanbaru \\ *Koresponden E-mail: ricky.yadi88@gmail.com
}

(Diterima 02 September 2020| Disetujui 28 Mei 2021 |Diterbitkan 17 Juli 2021)

\begin{abstract}
The needs for added value of agricultural products is increasing, both in the form of health benefits and of reducing pollution waste. The sorting-out fruits that are just wasted can still be used as materials that have added value. In general, fruits contain glucose which is the basic ingredient in processing of bioethanol. Even though the quality has decreased, it still contains glucose which can then be fermented into bioethanol or organic fertilizer. Recently, the pharmaceutical and food and beverage industries require a large supply of bioethanol for further processing according to the industrial needs. Meanwhile, agricultural land is increasingly promoting organic farming. The objective of this activity is to produce new products from fruit waste into bioethanol and organic fertilizers that are useful for both the community and the government so that they can be used as the right solution to reduce environmental pollution and create new business opportunities. Bioethanol processing method uses Saccharomyces cerevisiae as a biocatalyst and uses an EM4 activator to produce organic fertilizers. This activity produces an output product in the form of bioethanol $46.78 \%$ and organic fertilizer which contain $1 \% N$.
\end{abstract}

Keywords: Contamination, Waste fruit, Bioethanol, Organic fertilizers

\section{PENDAHULUAN}

Indonesia merupakan salah satu negara agraris yang menghasilkan komoditas pertanian cukup besar di dunia. Salah satu komoditas pertanian yang dihasilkan adalah buah-buahan. Salah satu karakteristik dari bahan pertanian terutama buah-buahan ialah sifatnya mudah membusuk. Sifat buah-buahan yang mudah busuk menyebabkan buah-buahan tersebut terbuang begitu saja. Hal ini dapat berdampak pada pencemaran lingkungan jika buah-buah sisa tersebut tidak ditangani lebih lanjut.

Peredaran buah-buahan di Kota Pekanbaru cukup besar baik di pasar-pasar tradisional, supermarket maupun tempat penjualan buah skala kecil yang tersebar luas di Pekanbaru. Ketersediaan buahbuahan ini tentu saja berdampak pada limbah yang dihasilkan yaitu berupa buah yang tidak layak dijual atau dikonsumsi kembali karena membusuk. Berikut total limbah kategori buah-buahan berdasarkan data yang diperoleh dari Dinas Kebersihan dan Pertamanan Kota Pekanbaru tahun 2015-2017. Berdasarkan data dari Dinas Kebersihan dan Pertamanan Kota Pekanbaru, periode tahun 2016 limbah buah-buahan mencapai 12.049 ton dan meningkat menjadi 13.091 ton pada tahun 2017. Hal ini menunjukkan bahwa ketersediaan limbah buahbuahan sangat berpotensi untuk diolah kembali menjadi produk turunan yang memiliki nilai tambah.

Menurut Panji Nugroho (2013) jenis sampah berdasarkan sifatnya, dibedakan menjadi dua kategori, yaitu: (1) Sampah organik, yaitu sampah yang bersifat mudah membusuk, contohnya daun-daun kering, sisa makanan, dan sebagainya; (2) Sampah anorganik, yaitu sampah yang bersifat tidak mudah membusuk, contohnya botol, plastik wadah pembungkus makanan, plastik mainan, kertas, gelas minuman, kayu, kaleng, dan sebagainya.

Hasil penelitian yang dilakukan oleh Atiqah, et al., (2014) menunjukkan bahwa limbah buah tomat dapat digunakan untuk produksi bioetanol. Perbedaannya dengan penelitian yang akan dilakukan adalah jumlah variasi bahan baku yang digunakan dan tambahan output berupa pupuk organik.

Hasil penelitian yang dilakukan oleh Pratiwi (2010) terkait produksi bioetanol dengan memanfaatkan kulit buah cokelat diperoleh hasil yaitu pada proses hidrolisis kadar glukosa yang terbaik $25,5 \%$, berat kulit cokelat 25 gram. Sedangkan pada proses fermentasi kondisi terbaik dengan jumlah starter Saccharomyces Cerevisiae $10 \%$ berlangsung selama 6 hari, dapat menghasilkan bioetanol sebesar 10,90\%.

Louis Pasteur yang merupakan ilmuwan Perancis mengenalkan metode fermentasi gula dengan menggunakan mikroorganisme. Pada tahun 1815, Gay-Lussac juga memformulasikan sebuah konversi glukosa menjadi etanol dan karbondioksida. Adapun formulanya tersebut yaitu (Whitaker, 1995)

$\mathrm{C}_{6} \mathrm{H}_{12} \mathrm{O}_{6} \rightarrow 2 \mathrm{C}_{2} \mathrm{H}_{5} \mathrm{OH}+2 \mathrm{CO}_{2}$

Whitaker juga menjelaskan pada bukunya bahwa substrat yang dapat difermentasikan untuk menjadi alkohol yaitu: (1) Bahan yang mengandung gula (sugary materials) seperti tebu dan sisa produknya (molase, bagase), kentang manis, gula bit, sorgum 
manis, tapioca, dan sebagainya; (2) Bahan-bahan berpati (starchy materials) seperti padi, tapioka, barley, maizena, gandum, dan kentang; (3) Bahan-bahan lignoselulosa (lignosellulosic material) seperti sumber selulosa dan lignoselulosa yang berasal dari limbah pertanian dan kayu.

Glukosa merupakan senyawa organik yang juga disebut gula sederhana yang berbentuk karbohidrat berjenis monosakarida. Produksi etanol/ bioetanol (alkohol) yang menggunakan bahan baku dari tanaman yang mengandung pati/ karbohidrat, dapat dilakukan melalui proses konversi karbohidrat menjadi gula (glukosa) larut air. Reaksi yang terjadi saat proses produksi etanol ataupun bioetanol secara sederhana dapat dilihat pada reaksi berikut (Nurdyastuti, 2005).

$$
\begin{aligned}
& \mathrm{H}_{2} \mathrm{O} \\
& \left(\mathrm{C}_{6} \mathrm{H}_{10} \mathrm{O}_{5}\right) \mathrm{n} \text {--.--.---- } \rightarrow \mathrm{N} \mathrm{C}_{6} \mathrm{H}_{12} \mathrm{O}_{6} \\
& \text { (pati) enzim (glukosa) } \\
& \left(\mathrm{C}_{6} \mathrm{H}_{12} \mathrm{O}_{6}\right) \mathrm{n} \text {------- } \rightarrow 2 \mathrm{C}_{2} \mathrm{H}_{5} \mathrm{OH}+2 \mathrm{CO}_{2} \text {. } \\
& \text { (glukosa) yeast (etanol) }
\end{aligned}
$$

Secara singkat teknologi proses untuk memproduksi etanol ataupun bioetanol dapat dibagi menjadi tiga tahap, yaitu gelatinasi, sakharifikasi, dan fermentasi. Proses fermentasi dimaksudkan untuk mengubah glukosa menjadi etanol/bioetanol (alkohol) dengan menggunakan yeast untuk memurnikan bioetanol menjadi berkadar lebih dari 95\% agar dapat dimanfaatkan sebagai bahan bakar. Untuk memisahkan alkohol dengan air, alkohol hasil fermentasi yang mempunyai kemurnian sekitar 40\% harus melewati proses destilasi dengan memperhitungkan perbedaan titik didih alkohol dan air tersebut yang kemudian diembunkan kembali (Nurdyastuti, 2005). Hasil penelitian oleh Seftian (2012) menunjukkan bahwa proses fermentasi yang berlangsung sampai 5 hari, semakin banyak jumlah penggunaan enzim, maka kadar etanol yang dihasikan juga semakin tinggi. Kadar etanol yang dihasilkan semakin tinggi sampai 5 hari waktu fermentasi, namun setelah melewati waktu fermentasi 5 hari kadar etanol yang dihasilkan akan semakin menurun.

Hasil penelitian yang dilakukan Widyanti (2016) menyimpulkan bahwa Saccharomyces cerevisiae amobil dapat digunakan sebagai bio-katalis dalam pembentukan etanol. Etil alkohol atau etanol merupakan zat kimia yang termasuk ke dalam golongan alkohol. Etanol memiliki banyak manfaat karena Sifat polar yang dimilikinya, sering digunakan sebagai pengawet dalam dunia medis, pelarut obat, desinfektan serta biasanya digunakan sebagai anti dotum (senyawa untuk mengurangi atau menghilangkan toksisitas) keracunan metanol dan etil englikol (Arora et al., 2007). Selain itu, etanol memiliki titik didih sebesar 78,40C sehingga memiliki sifat mudah terbakar (Simanjuntak, 2009). Etanol memiliki struktur kimia $\mathrm{CH}_{3} \mathrm{CH}_{2} \mathrm{OH}$, dengan rumus struktur kirmia tersebut maka etanol memiliki sifat yang mudah menguap, tidak memiliki warna, dan bersifat polar sehingga dapat digunakan sebagai pelarut untuk berbagai senyawa (Sebayang, 2006). Etanol juga dapat dimanfaatkan sebagai campuran bahan bakar pada mesin kendaraan. Hasil penelitian oleh Agrariksa (2013) menunjukkan bahwa terjadi peningkatan daya mesin motor karena adanya penambahan oktan pada premium setelah ditambahkan etanol. Dengan adanya penambahan etanol pada mesin motor dapat mengoptimalkan reaksi pembakaran.

Selain pemanfaatan menjadi bioetanol, buah sisa juga dapat diolah menjadi pupuk organik. Salah satu metode pengolahan pupuk organik dengan menggunakan Teknologi Effective Microoorganisms (TEM). Menurut Wididana (1994), Effective Microorganisms (EM) merupakan kultur campuran dari mikroorganisme yang menguntungkan bagi petumbuhan tanaman. EM4 yang dikenal saat ini adalah EM4 yang digunakan sebagai inokulan untuk meningkatkan populasi mikroorganisme di dalam tanah dan tanaman, yang diharapkan dapat meningkatkan kesehatan, pertumbuhan, perkembangan, serta kuantitas dan kualitas produksi tanaman. Campuran bahan organik dan EM4 ini disamping dapat digunakan sebagai stater mikroorganisme yang menguntungkan yang terdapat dalam tanah juga dapat memberikan respon positif terhadap pertumbuhan dan perkembangan tanaman.

Adapun prinsip dari proses pengomposan adalah menurunkan rasio $\mathrm{C} / \mathrm{N}$ bahan organik hingga sama atau hampir sama dengan $\mathrm{C} / \mathrm{N}$ tanah $(<20)$, dengan demikian nitrogen dapat dilepas dan dapat dimanfaatkan oleh tanaman (Siboro et al, 2013). Proses pengomposan dapat terjadi secara aerobik (menggunakan oksigen) atau anaerobik (tidak ada oksigen). Jalaluddin et al., (2016) melakukan pengolahan sampah organik buah-buahan menjadi pupuk organik dengan menggunakan tambahan bioaktivator EM4. Hasil penelitian menunjukkan adanya korelasi anatara lama fermentasi dengan volume EM4 yaitu semakin lama waktu fermentasi dan semakin banyak volume EM4 yang digunakan maka semakin tinggi juga nilai $\mathrm{N}, \mathrm{P}$ dan $\mathrm{K}$ pupuk.

Tujuan dari penelitian ini adalah pemanfaatan buah sisa dapat mengurangi pencemaran lingkungan, memberikan nilai tambah terhadap buah sisa yang tidak termanfaatkan serta mampu menghasilkan bioetanol dari pemanfaatan buah sisa dan pupuk organik dari produk samping pembuatan bioetanol yang kemudian dapat digunakan dalam berbagai macam keperluan. 


\section{BAHAN DAN METODE}

\section{Bahan dan Alat}

Bahan yang digunakan pada penelitian ini adalah buah sisa atau limbah buah yang tidak layak dikonsumsi karena sudah mengalami proses pembusukan. Buah-buahan yang digunakan beragam seperti pisang, apel, jeruk, dan lainnya yang banyak tersedia di pasaran. Buah sisa yang digunakan sebanyak 2,5 kg dengan berbagai jenis buah (apel, jeruk, pear, pisang, salak, melon) yang diperoleh dari pasar Dupa di kelurahan Tangkerang Tengah kota Pekanbaru. Bahan tambahan yang juga digunakan pada penelitian ini adalah EM4 untuk pembuatan pupuk organik. Sedangkan alat-alat yang digunakan pada penelitian ini yaitu blender, penyaring dan juga menggunakan peralatan laboratorium.

\section{Metode Penelitian}

\section{Pembuatan bioetanol}

Metode pembentukan etanol berdasarkan hasil penelitian yang dilakukan Widyanti (2016) dengan menggunakan Saccharomyces cerevisiae sebagai biokatalis. Pada penelitian ini juga menentukan kadar etanol terbaik dengan perlakuan penambahan ZA atau tanpa ZA.

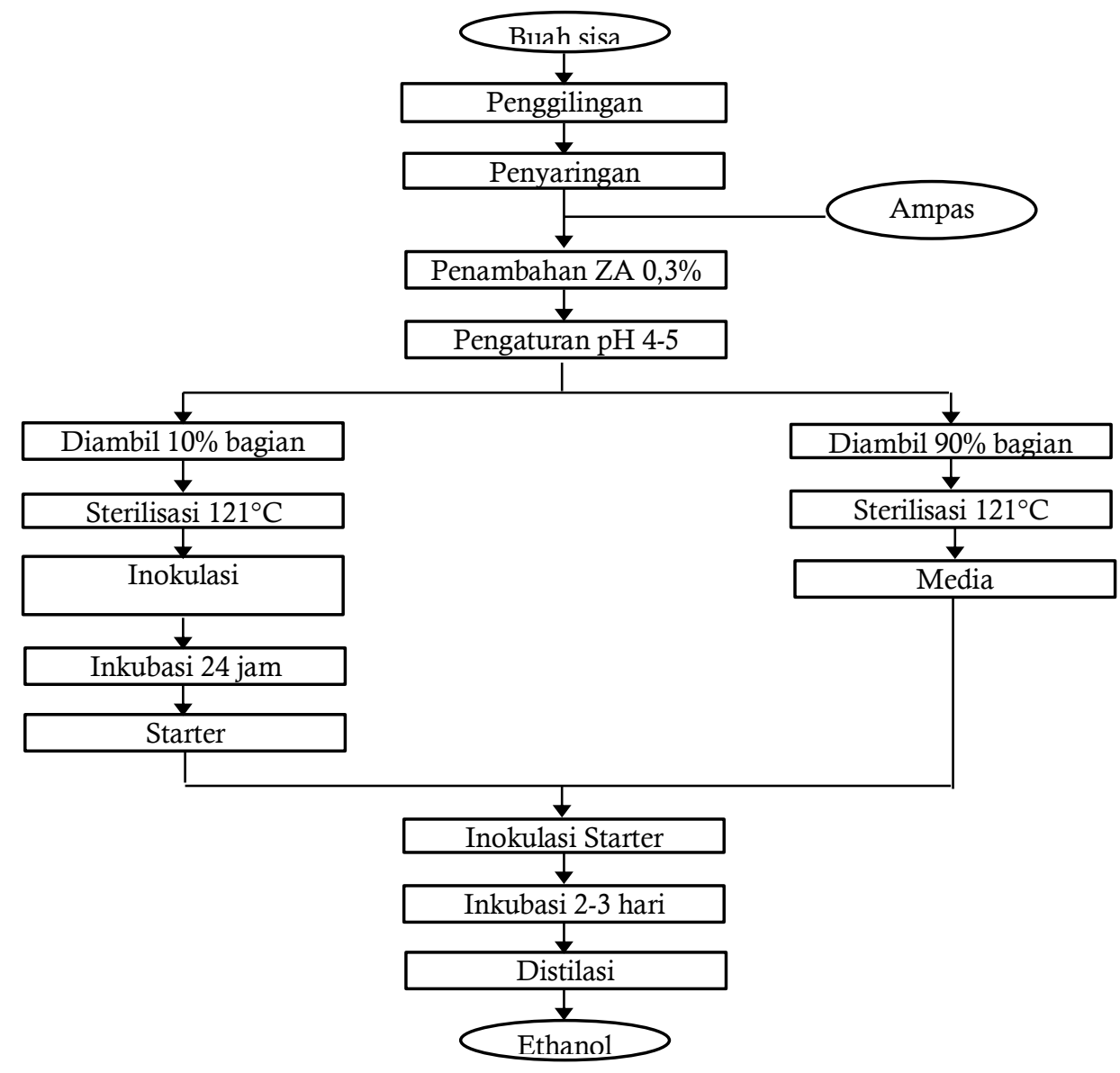

Gambar 1. Alur proses pembuatan Bio-ethanol

\section{Pembuatan Pupuk Organik}

Pembuatan pupuk organik menggunakan ampas hasil penyaringan untuk pembuatan etanol yang selanjutnya difermentasi menggunakan EM4.
EM4 berfungsi sebagai aktivator mempercepat proses pengomposan melalui proses fermentasi.

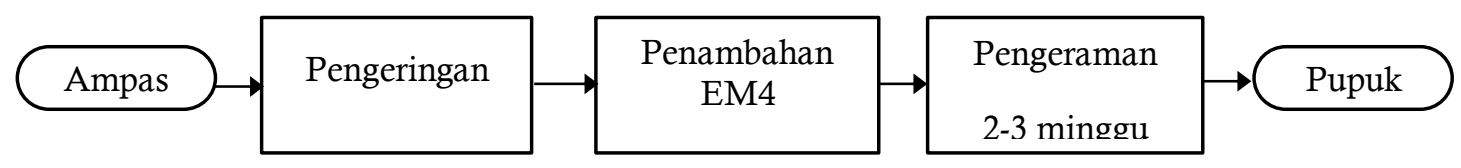

Gambar 2. Alur proses pembuatan pupuk organik 


\section{HASIL DAN PEMBAHASAN}

Pada penelitian ini menggunakan buah sisa sebanyak $1,8 \mathrm{~kg}$ dengan berbagai jenis buah (apel, jeruk, pear, pisang, salak, melon) dan kondisinya sudah tidak layak untuk dikonsumsi. Hasil proses dari blender dan penyaringan diperoleh cairan 1 liter, ampas buah $0,8 \mathrm{~kg}$. Cairan yang dihasilkan selanjut- nya akan diproses untuk pembuatan bioetanol sedangkan ampas yang dihasilkan selanjutnya diproses untuk dijadikan pupuk organik. Dari 1 liter cairan hasil penyaringan, selanjutnya dibagi 2 yaitu masingmasing $500 \mathrm{ml}$ untuk perlakuan yang berbeda. Adapun bioetanol yang dihasilkan ditunjukkan pada tabel berikut:

Tabel 2. Bioetanol Hasil Penelitian

\begin{tabular}{lll}
\hline & Penambahan ZA & Tanpa ZA \\
\hline Volume sampel (ml) & 500 & 500 \\
Distilat (ml) & 31 & 37 \\
Kadar etanol (\%) & 46,78 & 45,99 \\
\hline
\end{tabular}

Pembentukan etanol dilakukan dengan 2 perlakuan yaitu penambahan ZA dan tanpa ZA untuk melihat kadar etanol yang optimal. Hasil penelitian menunjukkan dengan adanya penambahan ZA dapat meningkatkan kadar etanol jika dibandingkan dengan proses tanpa ZA. Dari hasil penelitian diketahui bahwa buah sisa berpotensi untuk menghasilkan etanol. Dengan penambahan ZA, kadar etanol yang dihasilkan lebih tinggi yaitu 46,78 \% dimana volume sampel cairan yang digunakan sebanyak $500 \mathrm{ml}$ atau setengan dari total sampel cairan. Artinya dengan jumlah buah sisa yang digunakan pada penelitian ini sebanyak $1,8 \mathrm{~kg}$ dapat menghasilkan $62 \mathrm{ml}(2 \times 31 \mathrm{ml})$ etanol dengan kadar $46,78 \%$. Jika dikonversikan maka 1 ton buah sisa dapat menghasilkan $34.444 \mathrm{ml}$ etanol 46,78\%.

Ampas ataupun scrap dari proses pengolahan etanol buah sisa dapat dimanfaatkan sebagai pupuk organik dengan metode penambahan EM4. Dari 2,5 $\mathrm{kg}$ buah sisa yang digunakan dalam produksi bioetanol dihasilkan pupuk organik sebanyak 102 gram.

Selanjutnya dilakukan penghitungan kadar Nitrogen pada pupuk organik yang dihasilkan. Masukkan $10 \mathrm{ml}$ larutan ekstrak sampel pupuk ke dalam labu didih lalu tambah sedikit serbuk batu didih dan aquades hingga setengan volume labu. Siapkan penampung $\mathrm{NH}_{3}$ yaitu erlenmeyer yang berisi
$10 \mathrm{ml}$ larutan $\mathrm{H}_{3} \mathrm{BO}_{3} \quad 1 \%$ ditambah 2 tetes indikator metil merah dan dihubungkan dengan alat destilasi. Selanjutnya menambahkan $\mathrm{NaOH} 40 \%$ sebanyak 10 $\mathrm{ml}$ ke dalam labu didih yang berisi sampel dan secepatnya ditutup. Lalu didestilasi hingga volume penampung mencapai 50-75 $\mathrm{ml}$ (berwarna hijau). Destilat selanjutnya dititrasi dengan $\mathrm{HCl} 0,014 \mathrm{~N}$ hingga menjadi warna merah muda. Volume titar sampel (Vc) dan blanko (Vb) dicatat. Setelah itu dilakukan perhitungan dengan menggunakan rumus (Sulaeman et al., 2005).

$$
\text { Persentase kadar } \mathrm{N}=\frac{(\mathrm{ts}-\mathrm{b}) \text { ) } \mathrm{Normalitas} \mathrm{HCl} \text { x Ar N x fk 100\% }}{\text { massa sampel }}
$$

Hasil uji kandungan pupuk diketahui bahwa pupuk organik dari ampas buah sisa memiliki kadar Nitrogen $(\mathrm{N})$ sebesar $\pm 1 \%$. Unsur hara $\mathrm{N}$ merupakan unsur yang dibutuhkan dalam jumlah banyak sehingga unsur $\mathrm{N}$ disebut sebagai unsur hara makro primer. $\mathrm{N}$ berfungsi untuk menyusun asam nukleat, nukleotida, asam amino (protein) dan klorofil pada tanaman, sehingga dengan adanya unsur $\mathrm{N}$, tanaman akan Mempercepat pertumbuhan tanaman. Jika tanaman kekurangnya unsur $\mathrm{N}$ akan menyebabkan tanaman tersebut menjadi kerdil, pertumbuhan akar terbatas, serta daun menjadi kuning dan gugur (Ratnawati et al., 2016).

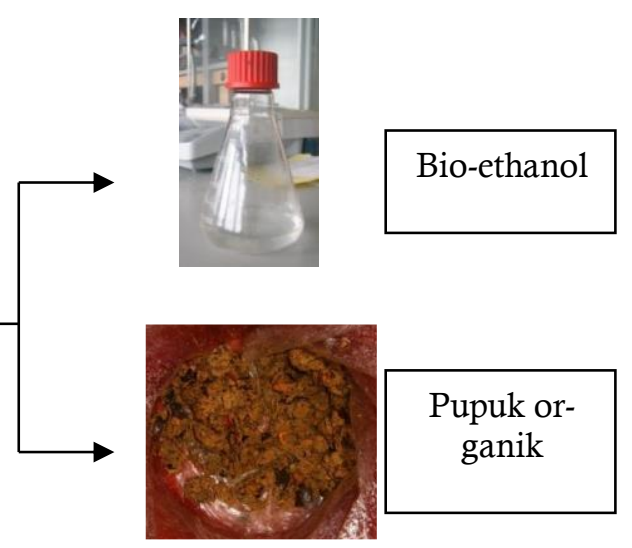

Gambar 3. Pemanfaatan buah sisa menjadi bioetanol dan pupuk organik 
Proses pembuatan bioetanol dan pupuk organik dilakukan bersamaan sehingga waktu pengolahannya lebih optimal. Melimpahnya buah sisa yang ada maka produksi bioetanol dan pupuk organik ini memiliki potensi yang cukup tinggi untuk diproses secara skala besar. Bahan baku yang digunakan dapat diperoleh dengan mengeluarkan biaya yang kecil bahkan dapat diperoleh secara gratis jika melakukan koordinasi atau kerja sama dengan pengurus supermarket atau pasar-pasar tradisional.

\section{SIMPULAN}

Besarnya potensi buah sisa yang ada di kotakota besar menjadi peluang besar untuk pemanfaatannya menjadi produk yang memiliki nilai tambah. Buah sisa berpotensi untuk dimanfaatkan menjadi Bioetanol yang berguna sebagai bahan baku industri farmasi maupun makanan dan minuman. Ampas yang dihasilkan dalam proses pembuatan bioetanol buah sisa dapat digunakan sebagai pupuk organik yang ramah lingkungan sehingga tidak ada limbah yang terbuang. Pemanfaatan buah sisa menjadi bioetanol dan pupuk organik diharapkan mampu mengurangi pencemaran dan jumlah sampah organik (buah) yang terdapat di kota-kota besar.

\section{UCAPAN TERIMA KASIH}

Penulis ingin mengucapkan terima kasih yang sebesar-besarnya kepada tim penyusun jurnal atas kerja samanya serta kepada Balai Pengembangan Produk dan Standardisasi Industri (BPPSI) Pekanbaru atas dukungan yang diberikan.

\section{DAFTAR PUSTAKA}

Agrariksa. (2013). Uji Performansi Motor bakar Bensin (On Chassis) Menggunakan Campuran Premium dan Etanol. Jurnal Keteknikan Pertanian Tropis dan Biosistem. Vol. 1 No. 3.

Arora, M., Koley, S., Gupta, S., \& Sandhu, J.S. (2007). A Study on Lipid Profile and Body Fat in Patients with Diabetes Melitus. Anthropologist, 9(4):295-8.

Atiqah, H.G., Romli, M., \& Suprihatin. (2014). Pemanfaatan Limbah Buah Tomat untuk Produksi Bioetanol Oleh Saccharomyces cerevisiae. IPB Bogor: UT - Agro-Industrial Engineering.
Jalaludin, Nasrul Z.A., \& Syafrina, R. (2016). Pengolahan Sampah Organik Buah-buahan menjadi Pupuk dengan Menggunakan Efektif Mikroorganisme. Jurnal Teknologi Kimia Unimal, 5-(1): 1729. https://doi.org/10.29103/jtku.v5i1.76

Nugroho, Panji. (2014). Panduan Pembuatan Pupuk Kompos Cair. Yogyakarta: Pustaka Baru Press.

Nurdyastuti, Indyah. (2005). Teknologi Produksi Bioetanol. Jurnal: Prospek Pengembangan Biofuel sebagai Substitusi Bahan Bakar Minyak.

Pratiwi, Eka, P., Yatim, M., \& Edahwati, L. (2010). Pemanfaatan Limbah Kulit Buah Cokelat Sebagai Bioetanol. Makalah Seminar Nasional Teknik Kimia Soebardjo Brotohardjono. D7: 1-10.

Ratnawati, R., Trihadiningrum, Y., \& Juliastuti, S.R. (2016). Composting of Rumen Content Waste Using Anaerobic-Anoxic-Oxic (A2O) Methods. Journal of Solid Waste Technology and Management, 42 (2): 98-106.

Sebayang, F. (2006). Pembuatan Etanaol Dari Molase Secara Fermentasi Menggunakan Sel Saccharomyces cerevisiae Pada Kalsium Alginat. Jurnal Teknologi Proses, 5 (2): 68-74.

Seftian, D., Antonius, F., \& Faizal, M. (2012). Pembuatan Etanol dari Kulit Pisang Menggunakan Metode Hidrolisis Enzimatik dan Fermentasi. Jurnal Teknik Kimia No. 1, Vol. 18.

Siboro, E.S., Surya, E., \& Herlina, N. (2013). Pembuatan pupuk cair dan biogas dari campuran limbah sayuran. Jurnal Teknik Kimia USU 2(3): 40-43.

Simanjuntak, Riswan. (2009). Studi Pembuatan Etanol dari Limbah Gula (Molase). Universitas Sumatera Utara.

Sulaeman, Suparto \& Eviati. (2005). Analisis kimia tanah, tanaman, air dan pupuk. Bogor: Balai Penilitian Tanah dan Pengembangan Penelitian, Departemen Pertanian.

Widyanti, E.M., \& Moehadi, B.I. (2016). Proses Pembuatan Etanol dari Gula Menggunakan Saccharomyces Cerevisiae Amobil. Jurnal METANA, Vol. 12(2):31-38. https://doi.org/10.14710/metana.v12i2.9751

Whitaker, A. (1995). Principle of Fermentation Technology 2nd Edition. Elsevier Scienci Ltd.

Wididana, G.N. (1994). Application of Effective Microorganism (EM) and Bokashi on Natural Farming. Bulletin Kyusei Nature Farming 03 (2): 47 54. 